\title{
Effects of potassium and carbon addition on bacterial algae bioremediation of boezem water
}

\author{
Indah Nurhayati ${ }^{\dagger}$, Rhenny Ratnawati, Sugito \\ Department of Environmental Engineering, Universitas PGRI Adi Buana Surabaya, Dukuh Menanggal XII Surabaya 60234, Indonesia
}

\begin{abstract}
Bioremediation of bacterial algae is one of wastewater treatment by utilizing symbiosis of bacterial algae, which is relatively inexpensive and safe for the environment. The aims of this research were: (1) to investigate initial characteristic of boezem water of Kalidami Surabaya, (2) to investigate the effect of potassium $(\mathrm{K})$ element and carbon source addition toward the reduction of $\mathrm{NH}_{3}-\mathrm{N}$ content and organic matter in $\mathrm{KMnO}_{4}$ of boezem water. The research conducted in a laboratory in batches without adding aeration. The initial stage of this research was conducting alga culture until it was obtained chlorophyll-a algae concentration of $3.5 \pm 0.5 \mathrm{mg} / \mathrm{L}$. The best result of range finding test was a comparison of boezem water volume with algal which were about $25 \%: 75 \%$. The research conducted in duplo over $18 \mathrm{~d}$. The result of the research can be concluded that boezem water of Kalidami Surabaya for the parameter of $\mathrm{pH}$, temperature, $\mathrm{NH}_{3}-\mathrm{N}$, dissolved oxygen, chemical oxygen demand, biological oxygen demand, and number of $\mathrm{KMnO}_{4}$ show that it enables to do bioremediation of bacterial algae. Decrease efficiency occurred in a reactor with the addition of element $\mathrm{K} 3 \%$ and source $\mathrm{C} \mathrm{NH}_{3}-\mathrm{N}$ and $\mathrm{KMnO}_{4}$ final content $0.164 \mathrm{mg} / \mathrm{L}$ and $30 \mathrm{mg} / \mathrm{L}$, respectively.
\end{abstract}

Keywords: Algae, Bacteria, Bioremediation, Boezem water, $\mathrm{KMnO}_{4}, \mathrm{NH}_{3}-\mathrm{N}$

\section{Introduction}

Boezem is a temporary rainwater pool. Boezem of Kalidami is one of the boezem in Surabaya. The Surabaya Government does not yet have the domestic waste treatment so the majority of domestic waste is directly discharged into the water body and empty into the boezem. Domestic waste contains high nutrient and organic substances [1]. Increased of nutrients, especially Nitrogen $(\mathrm{N})$ and Phosphor $(\mathrm{P})$ in water, whether derived from waste or from the decomposition of organic substances can cause eutrophication [2-4]. Eutrophication causes an increase in algae and aquatic plants, ecological disturbances mainly related to food chain and adaptation of aquatic organisms [2].

The high rate algae pond (HRAP) is a waste treatment with shallow oxidation ponds and using a combination of algal bacterial $[5,6]$. Photosynthesis of algae produces oxygen $\left(\mathrm{O}_{2}\right)$ that will used by heterophilic bacteria to degrade organic substances. Nutrients and carbondioxide $\left(\mathrm{CO}_{2}\right)$ from oxidation will be used by algae. HRAP waste treatment has some benefits that it is cost-effective and algae energy is converted to biofuel, biogas, and bio-

This is an Open Access article distributed under the term of the Creative Commons Attribution Non-Commercial License (http://creativecommons.org/licenses/by-nc/3.0/) which permits unrestricted non-commercial use, distribution, and reproduction in any medium, provided the original work is properly cited.

Copyright (C) 2019 Korean Society of Environmental Engineers ethane as biofuels [7], its reproduction is fast, non-pathogenic, the range of toxicity is extensive [8], useful for environmental sustainability [5], and environmentally friendly [9].

Several studies that have been conducted to examine the ability of microalgae in remediating polluted environments among others are HRAP in managing greywater on average can reduce biological oxygen demand $\left(\mathrm{BOD}_{5}\right)$ to $69 \%$, chemical oxygen demand (COD) to $62 \%, \mathrm{NO}_{3}$ to $23 \%, \mathrm{NH}_{4}$ to $52 \%, \mathrm{PO}_{4}$ to $43 \%$ [7]. Bioremediation of Porphyra leucosticta red algae can reduce metals Cd(II) and $\mathrm{Pb}(\mathrm{I})$ with maximum capacities of $31.45 \mathrm{mg} / \mathrm{g}$ and $36.63 \mathrm{mg} / \mathrm{g}$, respectively [10], Scenedesmus sp. can reduce Cr 98.63\% and $\mathrm{Cl}^{-}$54.18\% [11]. Microalgae can reduce $\mathrm{Cl}^{-} 66.98 \%$ [12]. Sago wastewater treatment with symbiosis of algal bacterial can decrease COD $90.29 \%$, BOD $82.74 \%$, TSS $84.52 \%$, nitrate $82.85 \%$, and phosphate $98.66 \%$, increase in dissolved oxygen (DO) $73.82 \%$, increase in $\mathrm{pH} 97.56 \%$ [13].

Algae growth affected by the availability of nutrients and the interaction of physical factors, such as $\mathrm{pH}$, light intensity, aeration, and biotic factors $[6,14,15]$. The high concentration of ammonia $\left(\mathrm{NH}_{3}-\mathrm{N}\right)$ and organic substances in the body of water indicate

Received August 3, 2018 Accepted November 10, 2018

${ }^{\dagger}$ Corresponding author

Email: indahnurhayati@unipasby.ac.id

Tel: +62-31-5041097 Fax: +62-31-5042804

ORCID: 0000-0003-0332-3799 
the contamination of water bodies, one of them caused by domestic waste [16]. Organic compounds, such as $\mathrm{COD}$ or $\mathrm{BOD}_{5}$ and nutrients, such as $\mathrm{N}, \mathrm{K}, \mathrm{P}$, carbon (C) are compounds needed for the growth of algae and bacteria [17]. Almost all types of algae have chlorophyll, so they can produce their own food through photosynthesis.

During the photosynthesis, algae needs $\mathrm{CO}_{2}$ and produce $\mathrm{O}_{2}$. Algae provide $\mathrm{O}_{2}$ for bacteria to carry out aerobic respiration so that it can degrade waste, then the bacteria produce $\mathrm{CO}_{2}$ which used for algae photosynthesis [13].

The study regarding the effect of adding $\mathrm{K}$ and $\mathrm{C}$ element to the reduction of $\mathrm{NH}_{3}$ and organic substances in the form of permanganate numbers $\left(\mathrm{KMnO}_{4}\right)$ in boezem water treatment contaminated with domestic waste has never been done. Therefore, this study intended to (1) Determine the characteristics of Kalidami boezem water in Surabaya, Indonesia, (2) Examine the effect of adding $\mathrm{K}$ element form of potassium dihydrogen phosphate $\left(\mathrm{KH}_{2} \mathrm{PO}_{4}\right)$ and $\mathrm{C}$ in the form of sucrose to the levels of $\mathrm{NH}_{3}-\mathrm{N}$ and organic substances in the form of permanganate numbers $\left(\mathrm{KMnO}_{4}\right)$ of boezem water.

\section{Materials and Methods}

This research started with an analysis of the initial characteristics of Kalidami boezem water in Surabaya, including pH, DO, COD, BOD, $\mathrm{NH}_{3}-\mathrm{N}$ and number of $\mathrm{KMnO}_{4}$. Analysis of COD using closed reflux titrimetry, BOD and DO using winkler method, $\mathrm{pH}$ using $\mathrm{pH}$ meter, $\mathrm{KMnO}_{4}$ using titrimetry.

This research conducted in three stages. The first stage is algae culture, in order that the algae that used for bioremediation are truly ready. Algae culture carried out until reaching chlorophyll $a$ concentration with amount of $3.5 \mathrm{mg} / \mathrm{L}$ [18]. Algae culture cultivation is done by adding the NPK fertilizers and aerated continuously. The analysis of chlorophyll $a$ was conducted using spectrophotometric method $[19,20]$. The algae that are grown derived from freshwater ponds in Wonorejo, Surabaya. Algae culture was carried out for $5 \mathrm{~d}$ and resulting in chlorophyll $a$ with amount of $5.8 \mathrm{mg} / \mathrm{L}$.

The second stage is range finding test (RFT). RFT aims to determine the comparison between the volume of boezem water and algae that can still be tolerated its existence by the algae. The volume comparison between boezem water and algae in RFT that is $25 \%$ boezem water: $75 \%$ algae, $50 \%$ boezem water: $50 \%$ algae, and $75 \%$ boezem water: $25 \%$ algae. The reactor for RFT is a glass reactor with a volume of 4 liters. RTF was done until obtained a concentration of chlorophyll $a$ with a minimum of $3.5 \mathrm{mg} / \mathrm{L}$. The best RTF is obtained in conditions with a comparison of boezem water: algae culture is $25 \%$ : $75 \%$, for 7 (seven) d with concentration of chlorophyll $a$ amounted to $3.8 \mathrm{mg} / \mathrm{L}$.

The third stage is the Kalidami Surabaya boezem water treatment. This study conducted with a batch system, in a laboratory scale using a glass reactor with a volume of 8 liters, with additional variations of $\mathrm{K}$ and $\mathrm{C}$ elements and without aeration. The source of $\mathrm{K}$ element used $\mathrm{KH}_{2} \mathrm{PO}_{4}$ salt with variations in concentrations of $0 \%, 1 \%$, and $3 \%$. The source of $\mathrm{C}$ element used sucrose, with variations of $0 \mathrm{mg} / \mathrm{L}$ and $29.4 \mathrm{mg} / \mathrm{L}$. This study
Table 1. Experinment Condition

\begin{tabular}{lcc}
\hline Reactor & $\mathbf{K H}_{\mathbf{2}} \mathbf{P O}_{\mathbf{4}} \mathbf{( \% )}$ & Sucrosa $\mathbf{( m g} / \mathbf{L})$ \\
\hline 0T (K 0\%) & 0 & 0 \\
1T (K 1\%) & 1 & 0 \\
3T (K 3\%) & 3 & 0 \\
0G (K 0\%, C) & 0 & 29.4 \\
1G (K 1\%, C) & 1 & 29.4 \\
3G (K 3\%, C) & 3 & 29.4 \\
K & 0 & 0 \\
\hline
\end{tabular}

was done in two repetitions or duplo. This study also used a control reactor namely the reactor without the addition of algae, $\mathrm{K}$ and $\mathrm{C}$ elements. The reactor code is presented in Table 1. Bioremediation was done for $18 \mathrm{~d}$, analysis of $\mathrm{NH}_{3}-\mathrm{N}$ and $\mathrm{KMnO}_{4}$ was carried out on day $0,3,6,9,11,13,16$ and 18. The analysis of $\mathrm{NH}_{3}-\mathrm{N}$ with SNI method 06 6989.30-2005 [21] and analysis of organic substances in the form $\mathrm{KMnO}_{4}$ using SNI method 06 6989.22-2004 [22].

\section{Results and Discussion}

\subsection{Initial Characteristics of Kalidami Boezem Water}

The characteristics of Kalidami boezem water are presented in Table 2. The results of the initial analysis of Kalidami boezem water, $\mathrm{pH}$ ranging from $7.48 \pm 0.00$ shows that the $\mathrm{pH}$ of boezem water is at neutral $\mathrm{pH}$ so it allows microorganisms to grow normally. The concentrations of $\mathrm{DO}$ ranging from $0.00 \pm 0.00 \mathrm{mg} / \mathrm{L}$, the boezem water conditions was muddy, this show that boezem water contains a lot of suspended solids and microorganisms that can be used as seeding processes. From the results of the analysis of the initial characteristics of the Kalidami boezem water demonstrated that the activity of microorganisms in boezem water was quite high to decompose organic compounds and oxidate nutrients but the DO levels were low so that the life of microorganisms was disturbed, therefore water treatment needed to increase the DO of boezem water.

The level of $\mathrm{BOD}_{5} 52.70 \pm 0.17 \mathrm{mg} / \mathrm{L}$ and COD $122.20 \pm 0.20$ $\mathrm{mg} / \mathrm{L}$. The ratio of $\mathrm{BOD}_{5} / \mathrm{COD}$ was 0.43 , still in the range of $0.30-0.80$, indicates that water is easy to decompose naturally [23]. This shows that $43 \%$ of Kalidami boezem water is biodegradable, a category of untreated water [24]. From the data of ratio number of $\mathrm{BOD}_{5} / \mathrm{COD}$, it can be concluded that the Kalidami boezem water is suitable for biological treatment.

Table 2. Characterization Boezem Kalidami Surabaya

\begin{tabular}{clccc}
\hline No & Parameter & Unit & Standard $^{*}[17]$ & Results \\
\hline 1 & $\mathrm{pH}$ & - & $6-9$ & $7.48 \pm 0.00$ \\
2 & $\mathrm{DO}$ & $\mathrm{mg} / \mathrm{L}$ & $\geq 3$ & $0.00 \pm 0.00$ \\
3 & $\mathrm{NH}_{3}-\mathrm{N}$ & $\mathrm{mg} / \mathrm{L}$ & - & $10.82 \pm 0.7$ \\
4 & $\mathrm{COD}$ & $\mathrm{mg} / \mathrm{L}$ & 50 & $122.2 \pm 0.2$ \\
5 & $\mathrm{BOD}_{5}$ & $\mathrm{mg} / \mathrm{L}$ & 6 & $52.7 \pm 0.17$ \\
6 & $\mathrm{KMnO}_{4}$ & $\mathrm{mg} / \mathrm{L}$ & - & $62.8 \pm 0.09$ \\
\hline
\end{tabular}


The level of $\mathrm{NH}_{3}-\mathrm{N}$ was $10.82 \pm 0.70 \mathrm{mg} / \mathrm{L}$. The $\mathrm{NH}_{3}-\mathrm{N}$ in boezem water shows that organic nitrogen is converted by bacteria into ammonia [16]. Nitrification bacteria decompose ammonia into nitrite and nitrate. Nitrate is used by algae and other plants to form proteins. The nitrite content in water shows the amount of oxidized nitrogen. Nitrite is one of the important elements for the synthesis of plant proteins. The high content of nitrite and phosphate in the water can stimulate unlimited algae growth, so DO of water will decrease.

The number of $\mathrm{KMnO}_{4}$ of Kalidami boezem water was 62.80 $\pm 0.09 \mathrm{mg} / \mathrm{L}$, this condition shows that boezem water is contaminated by organic substances. Organic substances are food for microorganisms. The existence of organic substances caused the water to become muddy, have a color, taste and smells bad, and low of DO. The higher the content of organic substances shows that the water is increasingly polluted.

\subsection{Changes in $\mathrm{NH}_{3}-\mathrm{N}$ Levels}

The effect of adding $\mathrm{K}$ and $\mathrm{C}$ elements to $\mathrm{NH}_{3}-\mathrm{N}$ levels is presented in Fig. 1. This showed that the addition of $\mathrm{K}$ (in the form of $\mathrm{KH}_{2} \mathrm{PO}_{4}$ ) and $\mathrm{C}$ (in the form of sucrose) elements affect the levels of $\mathrm{NH}_{3} \mathrm{~N}$. At the beginning of the study, the $\mathrm{NH}_{3}-\mathrm{N}$ levels were $10.82 \pm 0.70 \mathrm{mg} / \mathrm{L}$, then it decreased fluctuatively. On day 3, the $\mathrm{NH}_{3}-\mathrm{N}$ levels experienced reduction drastically, especially in reactor with the addition of $\mathrm{K}$ elements without the addition of $\mathrm{C}$ element $(0 \mathrm{~T}, 1 \mathrm{~T}, 3 \mathrm{~T}$ ) the average decline was $61 \%$ and the reactor with the addition of $\mathrm{K}$ and $\mathrm{C}(0 \mathrm{G}, 1 \mathrm{G}, 3 \mathrm{G})$ elements was $76 \%$. In the control of reactor $(\mathrm{K})$ the reduction of $\mathrm{NH}_{3}-\mathrm{N}$ on day 3 was only $21 \%$.

The highest control reactor and treatment reactor reduction of $\mathrm{NH}_{3}-\mathrm{N}$ were achieved on day 16. The highest control reactor reduction of $\mathrm{NH}_{3}-\mathrm{N}$ was $90 \%$, the reactor with the addition of $\mathrm{K}$ element (0T, 1T, 3T) was the highest decrease on an average by $96 \%$ and the reactor with the addition of $\mathrm{K}$ and $\mathrm{C}$ elements (0G, 1G, 3G), the highest reduction of $\mathrm{NH}_{3}-\mathrm{N}$ on average by $98 \%$. On the 18th day, the control reactor and the treatment reactor experienced an increase in the levels of $\mathrm{HN}_{3}-\mathrm{N}$.

The reduction of $\mathrm{NH}_{3}-\mathrm{N}$ happened because of the nitrification process, nitrite bacteria (nitrosomonas) oxidate ammonia into nitrite $[5,16]$. Nitrosomonnas sp. functions as ammonia converters to nitrite. Nitrobacter sp. functions as a converter of nitrite to nitrate. The high nitrate content will be used by Chlorella sp. as nutrient [13]. The reduction of $\mathrm{NH}_{3}-\mathrm{N}$ in the control reactor is caused by the process of decomposition and absorption of organic materials by bacteria. The reduction of $\mathrm{NH}_{3}-\mathrm{N}$ levels in the treatment reactor because of the symbiotic process of algal bacterial in biodegradation of organic substance of boezem water. In the metabolic process, heterotrophic bacteria degrade organic substances into inorganic substances which absorbed by algae during photosynthesis. The results of photosynthesis in the form of water $\left(\mathrm{H}_{2} \mathrm{O}\right), \mathrm{O}_{2}$ and energy. $\mathrm{O}_{2}$ is used by bacteria to decompose organic substances in boezem water [13]. The more the algae that grow, then the more the inorganic compounds are used as algae nutrients so that $\mathrm{NH}_{3}-\mathrm{N}$ is decreasing.

Fluctuations of the reduction of $\mathrm{NH}_{3}-\mathrm{N}$ levels happen because of the availability of nutrients in boezem water. At the beginning of the study is adaptation phase (lag), bacteria acclimatize to
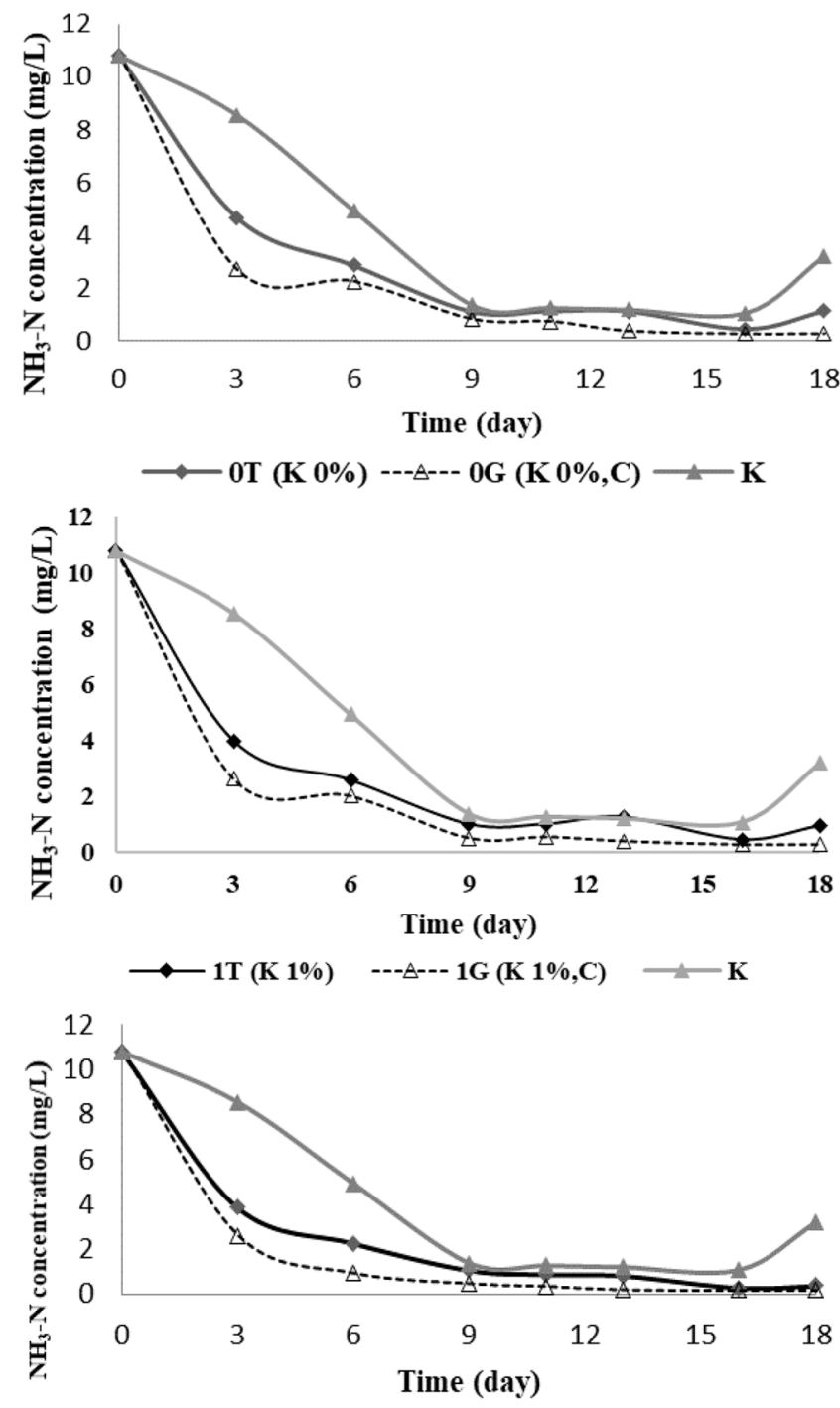

\section{$\longrightarrow-3 \mathrm{~T}(\mathrm{~K} \mathrm{3} \%) \quad---\mathrm{A}---3 \mathrm{G}(\mathrm{K} 3 \%, \mathrm{C}) \quad \longrightarrow \mathrm{K}$}

Fig. 1. The effect of adding potassium $(\mathrm{K})$ and carbon $(\mathrm{C})$ to the $\mathrm{NH}_{3}-\mathrm{N}$ levels.

$\mathrm{pH}$, temperature and nutrient, not much use of nutrients for its growth, bacteria metabolize but the fission has not been significant so that the increased number of bacteria is slow [14, 25].

On the 3rd to 9th day, the reduction of $\mathrm{NH}_{3}-\mathrm{N}$ occur drastically, this phase is referred to as the exponential phase. The exponential phase of bacterial growth is very fast, because nutrients are still high so microorganisms are used for maximum growth [14, 25]. The exponential phase is stopped due to the decreasing nutrient so that the population of bacteria and algae also decreases.

On the 9th day until the 16th day was the stationary phase, the concentrations of $\mathrm{NH}_{3}-\mathrm{N}$ tended to be permanent, though the reduction was not too large. This phase demonstrated that bacteria do not experience exponential growth and bacterial growth is balanced by cell death, due to the reduction of nutrients and energy reserves in the media [14, 25]. 
On the 18th day is the phase of death, marked by the rate of death which is faster than the rate of bacterial growth [14]. The increase of $\mathrm{NH}_{3}-\mathrm{N}$ levels happen because of ammonification by bacteria that converts $\mathrm{N}$-organic to ammonium and decomposition of living things that has been dead [26].

From this study it can be seen that the addition of $\mathrm{K}$ and $\mathrm{C}$ elements has an effect to the levels of $\mathrm{NH}_{3}-\mathrm{N}$ though there are little differences. The reactor with the addition of $3 \% \mathrm{~K}$ and $\mathrm{C}$ elements $29.4 \mathrm{mg} / \mathrm{L}$ (3G reactor) had the largest reduction value of $\mathrm{NH}_{3}-\mathrm{N}$ by $98 \%$ on the 16th day with the $\mathrm{NH}_{3}-\mathrm{N}$ levels was $0.16 \pm 0.01 \mathrm{mg} / \mathrm{L}$. This happen because in the reactor the nutrients for the growth of symbiotic algae-bacterial are sufficient so the process of decomposing organic substances in the boezem water is optimal. The addition of $\mathrm{KH}_{2} \mathrm{PO}_{4}$ and $\mathrm{K}_{2} \mathrm{HPO}_{4}$ functions as a buffer, namely the $\mathrm{pH}$ controller affects bacterial cell density. The higher the cell density, then the more acid is released into the media, with buffer then the $\mathrm{pH}$ can be maintained [17]. Sucrose as a food source and bacterial energy [25]. The addition of $\mathrm{N}$, $\mathrm{C}$ and $\mathrm{P}$ sources will increase cell growth and density [17].

\subsection{Changes in $\mathrm{KMnO}_{4}$ Levels}

The effect of adding $\mathrm{K}$ and $\mathrm{C}$ elements to the number of $\mathrm{KMnO}_{4}$ is presented in Fig. 2. The initial number of $\mathrm{KMnO}_{4}$ for boezem water was $62.80 \pm 0.09$. All treatment reactors experienced reduction of $\mathrm{KMnO}_{4}$ numbers drastically on day 3. The reactor with the addition of $\mathrm{K}$ and $\mathrm{C}(0 \mathrm{G}, 1 \mathrm{G}, 3 \mathrm{G})$ on the 3rd day experienced the highest average reduction of $\mathrm{KMnO}_{4}$ number by $45 \%$ and the reactor with the addition of $\mathrm{K}$ without the addition of $\mathrm{C}$ (0T, $1 \mathrm{~T}, 3 \mathrm{~T}$ ) has the highest reduction on average by $38 \%$. Whereas the control reactor reduced by only $21 \%$. It started on the 6 th day, the number of $\mathrm{KMnO}_{4}$ in all reactors are fluctuated but still experienced reduction until the 13th day. All reactors on day 13 experienced an increase in the number of $\mathrm{KMnO}_{4}$.

The reduction of the number of $\mathrm{KMnO}_{4}$ is drastically happen on the 3rd day was due to the availability of organic substances in boezem water so the microorganisms grow rapidly, so that the organic substances will also degraded quickly. The exponential phase occurs at the beginning of the study because of the abundance of nutrients [14]. The reduction in organic substances in the reactor treatment happens because of the symbiosis of algae with bacteria. The photosynthesis of microalgae will produce $\mathrm{O}_{2}$, which will be used by bacteria for their life and degrade organic substances into $\mathrm{CO}_{2}$, then $\mathrm{CO}_{2}$ is used by microalgae for photosynthesis [15]. Heterotrophic bacteria convert elements in boezem water into organic substances, which will degraded by algae in the process of photosynthesis into $\mathrm{H}_{2} \mathrm{O}, \mathrm{O}_{2}$ and energy [13]. Organic substances in boezem water are also used as a nutrient source for bacterial growth [15], so there is a reduction in organic substances in the form of $\mathrm{KMnO}_{4}$ numbers.

The highest reduction in the number of $\mathrm{KMnO}_{4}$ was occur in the reactor with the addition of $3 \% \mathrm{~K}$ element and the addition of C element $29.40 \mathrm{mg} / \mathrm{L}$ (3G reactor) on day 11, with an efficiency reduction of $\mathrm{KMnO}_{4}$ numbers by $52 \%$ and the final $\mathrm{KMnO}_{4}$ number was $29.50 \pm 0.70 \mathrm{mg} / \mathrm{L}$. This happens because the addition of $\mathrm{K}$ element $3 \%$ and $\mathrm{C}$ element $29.40 \mathrm{mg} / \mathrm{L}$ causes adequate nutrient requirements for the growth of algae-bacterial symbiosis. The

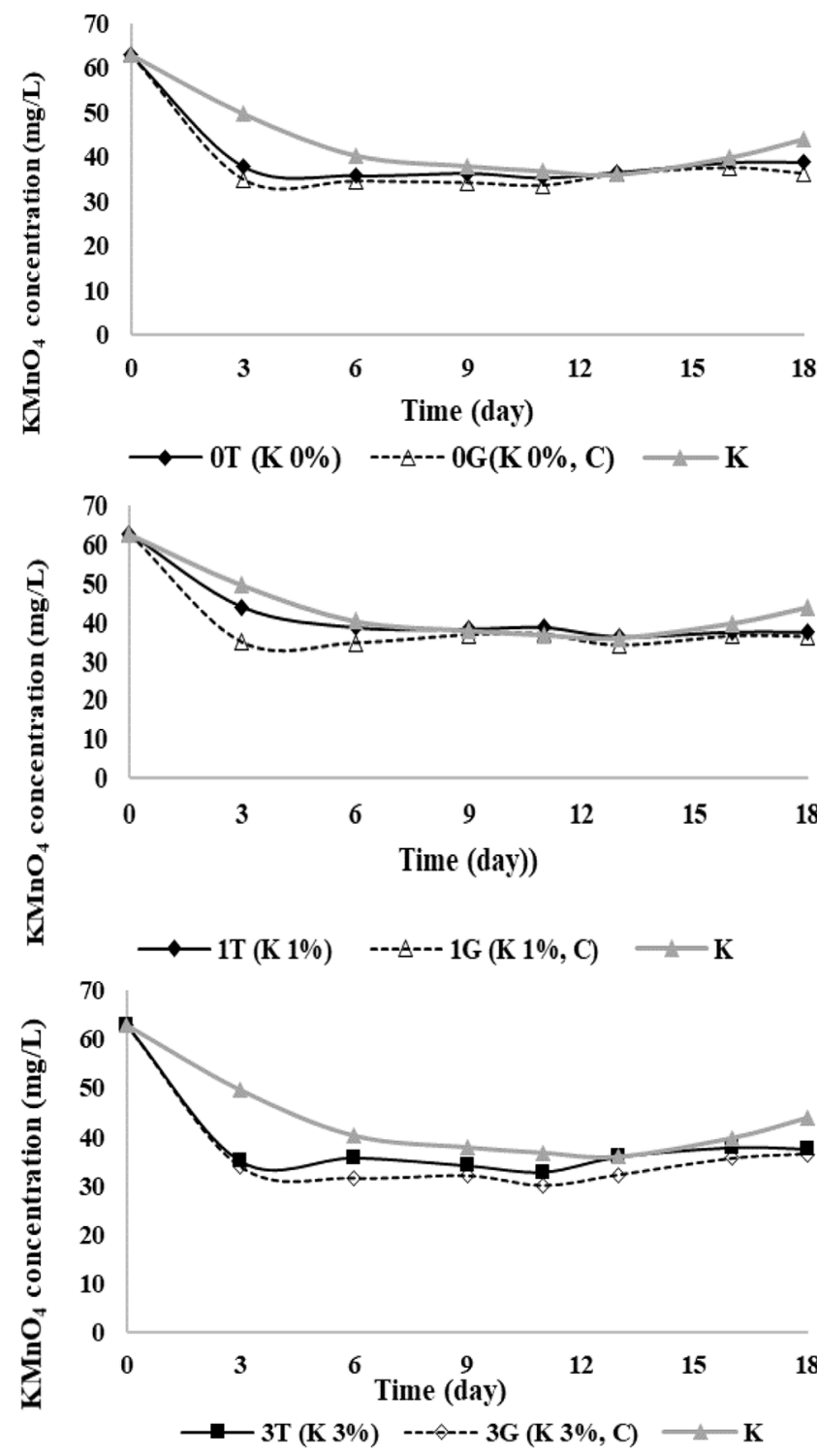

Fig. 2. The effect of adding $\mathrm{K}$ and $\mathrm{C}$ to the organic substances.

nutrients needed by myroorganisms for growth are $\mathrm{C}, \mathrm{N}, \mathrm{S}, \mathrm{P}$, $\mathrm{Ca}, \mathrm{Zn}, \mathrm{Na}, \mathrm{K}, \mathrm{Cu}, \mathrm{Mn}, \mathrm{Mg}$, vitamins, water and energy [27]. The addition of $\mathrm{C}$ element (sucrose) functions as a source of energy [17], and co-substrate that can increase bacterial growth so that it can reduce the number of $\mathrm{KMnO}_{4}$. Potassium is a macro nutrient that functions to change the physical form of enzyme molecules, exposing active chemical sites which is suitable for reaction. The potassium also neutralizes various organic anions and other compounds in plants, which help stabilize the $\mathrm{pH}$ between 7 and 8, which is optimal for most of enzyme reactions. The potassium also plays a major role in the transportation of water and nutrients throughout the plants in xylem [28].

The increased of organic substances in boezem water is caused by the death of microorganisms that are no longer able to absorb nutrients in boezem water. The dead microorganisms will be 
released into boezem water so that the concentration of organic substances increases. This effect is referred to as depuration, that is the return of pollutants to the environment.

\section{Conclusions}

This research concludes that the boezem water of Kalidami Surabaya has $\mathrm{pH}$ value of $7.48 \pm 0.00$, DO of $0.00 \pm 0.00 \mathrm{mg} / \mathrm{L}$, $\mathrm{NH}_{3}-\mathrm{N}$ of $10.82 \pm 0.70 \mathrm{mg} / \mathrm{L}, \mathrm{COD}$ of $122.20 \pm 0.20 \mathrm{mg} / \mathrm{L}, \mathrm{BOD}_{5}$ of $52.70 \pm 0.17 \mathrm{mg} / \mathrm{L}$, and $\mathrm{KMnO}_{4}$ number of $62.80 \pm 0.09 \mathrm{mg} / \mathrm{L}$. These characteristics show that boezem water is possible to conduct a bioremediation of bacterial algae. The highest $\mathrm{NH}_{3}-\mathrm{N}$ reduction efficiency occurs in the reactor with the addition of $\mathrm{K} 3 \%$ and $\mathrm{C} 29.40 \mathrm{mg} / \mathrm{L}$ on day 16 with the decreasing efficiency of $98 \%$ and the final $\mathrm{NH}_{3}-\mathrm{N}$ level was $0.164 \pm 0.01 \mathrm{mg} / \mathrm{L}$. the highest decreasing efficiency of $\mathrm{KMnO}_{4}$ number occurs in the reactor with the addition of $\mathrm{K} 3 \%$ and $\mathrm{C} 29.40 \mathrm{mg} / \mathrm{L}$ on day 11 with the decreasing efficiency of $52 \%$ and the final $\mathrm{KMnO}_{4}$ number was $29.50 \pm 0.70 \mathrm{mg} / \mathrm{L}$.

\section{Acknowledgments}

Thank you to the Directorate of Higher Education, the Ministry of Research, Technology, and Higher Education of the Republic of Indonesia, which had funded this research through an applied product research grant (PPT) with the contract letter no. 111.3.4/LPPM/V/2017 dated May 4, 2017, based on the Letter of Agreement for the assignment of research for private university lecturers Kopertis Wilayah VII of the fiscal year 2017, No. 040/SPPH/K2/KM/2017 dated May 4, 2017. DIPA No. 042.06.1.401516/2017, dated December 6, 2016.

\section{References}

1. Al Kholif A, Ratnawati R. Removal ammonia $\left(\mathrm{NH}_{3}\right)$ in industrial chicken slaughterhouse by anaerobic biofilter. Proceeding Seminar International The 1st Seminar on Environment and Health Toward SDG's Achievement 2030 Integration System on Environment and Health Sustainability. Surabaya; 2016. p. 171-179.

2. Sentosa AA, Hedianto DA, Satria H. Allegations of eutrophication in Lake Matano are reviewed from the phytoplanton community and water quality. Limnotek Perairan Darat Tropis Di Indonesia 2017;24:61-73 [In Indonesian].

3. Piranti AS, Soedarmaji, Waluya G, Suawardi. Transport nutrient causes eutrophication from the water catchment area of the Mrica Banjarnegara water reservoir. Biosfer 2015;32: 66-73 [In Indonesian].

4. Piranti AS, Rahayu DRUS, Waluya G. Nutrient limiting factor for enabling algae growth of Rawapening Lake, Indonesia. Biosaintifika 2018;10:101-108.

5. Assemany PP, Calijuri ML, Couto EA. Algae/bacteria consortium in high rate pond: influence of solar radiation on the phytoplankton community. Ecol. Eng. 2015;154-162.
6. Slamet A, Mei I, Hermana J. Effect of nutrient enrichment, salinity, and $\mathrm{pH}$ on HRAP biokinetics with algae culture from Boezem Morokrembangan Surabaya. Proceeding of National Seminar Environmental Technologi XII. Institut Teknologi Sepuluh Nopember Surabaya. 2015. p. 51-60 [In Indonesian]

7. Maiga Y, Takahashi M, Somda TYK, Maiga AH. Greywater Treatment by High Rate Algal Pond under Sahelian Conditions for Reuse in Irrigation. J. Water Resour. Protect. 2015;7:1143-1155.

8. Purnamawati FS, Soeprobowati TR, Izzati M. Potential of Chlorella vulgaris Beijerink in heavy metal remediation Cd and $\mathrm{Pb}$ scale laboratory. BIOMA 2015;16:102-113 [In Indonesian].

9. Sati M, Verma M, Bora M, Rai JPN. Potential of algae in bioremediation of heavy metals: A review. Bull. Environ. Pharmacol. Live Sci. 2016;5:86-97.

10. Ye J, Xiao H, Xiao B, Xu W, Gao L, Lin G. Bioremediation of heavy metal contaminated aqueous solution by using red algae Porphyra leucosticta. Water Sci. Technol. 2015;72:1662-1666.

11. Losada VAR, Bonilla EP, Pinilla LAC, Serrezuela RR. Removal of chromium in wastewater from tanneries applying bioremediation with algae, orange peel and citrus pectin. Contemp. Eng. Sci. 2018;11:433-449.

12. Ramirez ME, Velez YH, Alzate LR. Potential of mikroalgae in the bioremediation of water with chloride content. Brazilian J. Biol. 2018;78:472-476.

13. Pasaribu J, Restuhadi F, Zalfiatri Y. Chlorella sp. symbiotic mutualis mikroalge with bacteria decomposing $\mathrm{B}-\mathrm{DECO}_{3}$ in reducing waste sago levels of pollutans. JOM Faperta 2018;5:1-13.

14. Selvika Z, Kusuma ABK, Herliany NE, Negara BFSP. The growth rate of the Chlorella sp. at different concentration of coal waste water. Depik 2016;5:107-112.

15. Simatupang D, Restuhadi F, Dahril T. Utilization symbiotic of mikroalgae Chlorella sp. and EM4 to reduce of pollutans sago liquid waste. JOM Faperta 2017;4:1-13.

16. Hibban M, Rezagama A, Purwono. Study of reduction in ammonia concentration in domestic liquid waste with aeromedia tubular plastic biofilter technology at the beginning of processing. Jurnal Teknik Lingkungan 2016;5:1-9 [In Indonesian].

17. Subagiyo, Margino S, Triyanto. The effect of the addition of various types of carbon, nitrogen, and phosphorus on Deman, Ragosa and Sharpe Medium (MRS) on the growth of selected lactic acid bacteria isolated from penaeid shrimp intestine. Jurnal Kelautan Tropis 2015;18:127-132 [In Indonesian].

18. Ratnawati R, Nurhayati I, Sugito. The performance of algae-bacteria to improve the degree of environmental health. In: 2nd International Symposium of Public Health (ISOPH 2017) - Achieving SDGs in South East Asia: Challenging and Tackling of Tropical Health Problems. p. 17-23.

19. Eaton AD, Clesceri LS, Greenberg AE. Standard methods for the examination of water and wastewater. 21th ed. Washington American Public Health Association; 2005.

20. Rosang CI, Wagey BT. Detrmination of chloropil pigment content on Halopia Ovalis Seagress in Malalayang Water. Jurna pesisir dan Laut. 2016;1:15-19.

21. Standar Nasional Indonesia [Indonesia National Standards] 
2005. SNI No. 06 6989.30-2005 [In Indonesian].

22. Standar Nasional Indonesia [Indonesia National Standards], 2005. SNI No. 06 6989.22-2004 [In Indonesian].

23. Contrera RC, Silva C, Silva GH, Morita DM, Zaiat M, Schalch $\mathrm{V}$. The "chemical oxygen demand/total volatile acid" ratio as anerobic treatability indicator for landfill leachates. Brazilian J. Chem. Eng. 2015;32:73-86.

24. Tamyiz M. Comparison of BOD COD ratio in upper and lower pond areas against biodegradability of organic materials. $J$. Res. Technol. 2015;1:9-15.

25. Mardalena. Growth phase of lactic acid bacteria of Tempoyak Originated from Jambi stored at room temperature. Jurnal Sain Peternakan Indonesia 2016;11:58-66.
26. Taroreh FL, Karwur F, Mangimbulude J. Nitrogen transformation in Sarongsong Hot Water in Tomohon City. Proceeding of National Seminar on chemical engineering the struggle for the development of chemical technology for the processing of Indonesia's natural resources. 2016;F6-1-6.

27. Anissah, Rahayu T. Alternative media for bacterial growth using a different source of carbohidrats. Proceedings of the National Seminar on XII Biology Education. FKIP UNS. 2015. p. 855-860.

28. Iyer G, Gupto Y, Menon S, Vaval P, Nagle V. Uptake of potassium by algae and potential use as biofertilizer. India J. Plant Physiol. 2015;20:285-288. 